\title{
EFFECT OF DIETARY SUPPLEMENTATION OF TURMERIC POWDER ON GROWTH PERFORMANCE, BEHAVIOR AND BLOOD BIOCHEMICAL PARAMETERS OF FAYOUMI BROILERS
}

\author{
MADEHA H.A. DARWISH ${ }^{1}$ and RAMADAN D. EL SHOUKARY ${ }^{2}$ \\ ${ }^{1}$ Department of Animal and Poultry Behavior and Management, Faculty of Veterinary Medicine, Assiut University, \\ 71526, Egypt. \\ ${ }^{2}$ Department of Animal Hygiene, Faculty of Veterinary Medicine, New Valley University
}

Received: 3 December 2019; Accepted: 18 January 2020

\begin{abstract}
The present study was undertaken to investigate the effect of dietary supplementation of turmeric (Curcuma longa) powder on the performance, carcass traits and behavior of native Fayoumi broiler. A total number of 120 one month old commercial male Fayoumi broilers with nearly similar weights were randomly distributed into three experimental groups each 40 birds in 4 replicates (10 bird/replicate). Birds in the first group were fed on standard basal diet without any addition ( control T1) while, Fayoumi broilers in the second and the third groups fed on the same basal diet supplemented with 0.5 and $0.75 \%$ turmeric powder (T2\&T3). Growth performance parameters, carcass traits, and behavioral parameters were assessed. The results showed that, there was a significant increased in body weight gain, feeding, drinking and sitting behavior, total protein, globulin, calcium, phosphorus and dressing percentage while, significant decrease in FCR, walking and standing behavior. Addition of turmeric powder in the second and third treatment had no significant effect on albumin level, relative weights of liver, gizzard, heart and spleen over six weeks of experimental period. Results of the current study concluded that using turmeric (curcuma longa) powder supplement in Fayoumi broiler diets improved growth performance and ingestive behavior, in addition, total serum protein, globulin, calcium, phosphorus and dressing percentage were increased significantly.
\end{abstract}

Keywords: Turmeric, Feeding behavior, Growth performance, Carcass traits, Fayoumi broilers

\section{INTRODUCTION}

In Egypt, the demand for broiler meat is increased rapidly, driven by increased income and population growth and urbanization. Thus, broiler farming seems to be a considerable part of meat production and consumption. Poultry is one of the short duration and efficient avenue to convert the agro-industrial by-products and wastes into a high quality protein for human consumption.

Native Egyptian chickens (Fayoumi breed) become a profitable and most popular income generating sector for the educated unemployed youth in rural regions. Most of the poultry farmers are interested in its production because it survive normally with farmers as a scavenger bird showed a strong inherent scavenging, also have the carcass characteristics and flavor desired by Egyptian consumers. In addition to less prone to predator attacks and can survive under harsh nutritional and environmental conditions.

Corresponding author: Dr. Ramadan D. EL Shoukary E-mail address: ramadandardeer8@gmail.com

Present address: Department of Animal Hygiene, Faculty of Veterinary Medicine, New Valley University
Moreover, such breed demonstrated better general disease resistance than imported breeds, because they have evolved through natural selection for a long period in the prevailing environment (Ramadan et al., 2011).

Success on rearing broilers for maximum weight gain is not only depends upon the strain of the birds and management but also on high quality feed (Nazeer et al., 2002). Hence, it is essential to enhance the feeding value of available feed resources so as to improve the efficiency of feed utilization and minimize the cost of feed per kilogram live weight gain (Zhang et al., 2009).

The feed additives are a cluster of nutrient and nonnutrient composites which help in improving the efficiency of feed utilization and consequently dropping the high cost of feeds. These additives have established a great consideration as feed supplements for numerous purposes in poultry production throughout the recent years (Zhang et al., 2009).

Phytobiotics have gained increasing interest as natural growth promoting feed additives in broiler production in recent years. These have wide range of 
medicinal properties with no residual side effects (Rahman et al., 2014). Beneficial effects of these substances in poultry nutrition are due to their high content of pharmacologically active compounds stimulating appetite and feed intake, improving endogenous digestive secretion and activating immune responses (Nouzarian et al., 2011).

Several studies on broilers fed on phytogenic blends of coriander, turmeric, thyme and others have been indicated considerable improvement in growth performance, immune indicators and carcass characteristics in both broiler chicken and ducks (Qasem et al., 2015 and Hady et al., 2016). Phytogenic blends used singly or in combination as feed additives in animal feeds (Valenzuela-Grijalva et al., 2017). Among the various spices turmeric (Curcuma longa L), also known as the golden spice, is of special interest owing to its wide range of beneficial pharmacological effects in supportive of the health and well-being of both animals and humans (Prasad et al., 2014).

Turmeric (Curcuma longa) is a member of Zingiberacae family and one of herbs which contained an active component named curcumin (Mashhadani, 2015). It has a multitude effects including antioxidant, anti- inflammatory, antimicrobial, and gastroprotective, (Prasad et al., 2014). It also posses immune-modulatory and hepatoprotective properties (Rajput et al., 2013).
Accordingly, the aim of the present study was conducted to investigate the effect of dietary supplementation of curcumin powder on production performance; behavior and blood serum metabolites of Fayoumi broiler chickens.

\section{MATERIALS AND METHODS}

This research was carried out at the research unit of animal behavior and management, Veterinary medicine hospital, Assiut University, Assiut, Egypt.

\section{Birds and housing}

120 one month old male fayoumi broilers were purchased from a local commercial farm and assigned into three treated groups each of 40 birds in 4 replicates (10 birds / replicate). Birds were reared in isolated deep-litter floor pens for 42 days (from 30 to 72 days of age) and fed ad libitum on the respective diets and give free access to fresh water.

\section{Dietary treatments}

Birds were fed on commercial grower-finisher diet showed in table (1) for the 6 weeks of fattening period. In the first group, birds were fed ad libitum on basal grower-finisher diet (control diet), while fayoumi broilers in the second and third groups fed on the same diet supplemented with 0.5 or $0.75 \%$ turmeric powder.

Table1: Physical composition and energy value of the different experimental diets.

\begin{tabular}{|c|c|c|c|}
\hline \multirow[t]{2}{*}{ Ingredient (\%) } & \multicolumn{3}{|c|}{ Turmeric powder (\%) } \\
\hline & Control & $\begin{array}{c}\mathbf{T}_{1} \\
(0.5 \%)\end{array}$ & $\begin{array}{c}\mathbf{T}_{2} \\
(\mathbf{0 . 7 5})\end{array}$ \\
\hline \multicolumn{4}{|l|}{ Physical composition $\%$} \\
\hline Yellow corn, ground & 62.63 & 62.08 & 62.26 \\
\hline Soybean meal & 27.95 & 27.60 & 27.93 \\
\hline Sunflower oil & 2.87 & 2.80 & 2.43 \\
\hline Corn gluten meal & 3.19 & 3.65 & 3.34 \\
\hline Turmeric (Curcuma longa) & 0 & 0.5 & 0.75 \\
\hline Limestone, ground & 1.66 & 1.67 & 1.67 \\
\hline Mono calcium phosphate & 1.06 & 1.06 & 1.06 \\
\hline Methionine & 0.04 & 0.04 & 0.05 \\
\hline Common salt & 0.30 & 0.30 & 0.30 \\
\hline Premix* & 0.30 & 0.30 & 0.30 \\
\hline \multicolumn{4}{|l|}{ Chemical composition (\%) } \\
\hline Crude protein & 20 & 20 & 20 \\
\hline Ether extract & 5.76 & 5.76 & 6.34 \\
\hline Methionine & 0.38 & 0.38 & 0.38 \\
\hline Calcium & 0.90 & 0.90 & 0.90 \\
\hline Phosphorus, available & 0.35 & 0.35 & 0.35 \\
\hline Crude fiber & 3.20 & 3.25 & 3.26 \\
\hline \multicolumn{4}{|l|}{ Energy value: } \\
\hline $\mathrm{ME}(\mathrm{kcal} / \mathrm{kg})$ & 3100 & 3100 & 3100 \\
\hline
\end{tabular}




\section{Management and data collection:}

\section{Growth and feed efficiency traits}

Body weights of the birds were recorded weekly throughout the experiment period using a digital scale. Feed intake (FI) was calculated as the difference between the feed weighed in and unconsumed weighed back at the end of each period. Feed conversion ratio (FCR) was weekly calculated by dividing the feed intake by the weight gain.

\section{Behavioral parameters}

Behavior of 40 birds per treatment (10 bird $\mathrm{x} 4$ replicate) were observed according to a predefined ethogram (Table 2) using instantaneous scanning sampling method (Altmann, 1974), twice a day in morning from 0800 to 0900 and late afternoon from 1400 to 1500 , for 3 days weekly (MondayWednesday) during the entire experiment (from 30 to 72 days of age). The 12 pens were divided into 3blocks, and each block contains all treatments. Behaviors of all birds in one block (i.e. 4 pens) were scored every min during $4 \mathrm{~min}$. After sampling one block, moved to another block to repeat the same behavioral observation. In total, behavior of each treatment was scanned 12 times on each day (3 replicate X 2 cycle per period scored 6 times/hour). Data are presented as the proportion of each behavioral frequency (number of scans out of the total number possible) (Kristensen et al., 2006).

Table 2: behavior Ethogram

\begin{tabular}{|c|c|}
\hline Behavior & Definition \\
\hline \multicolumn{2}{|c|}{ Ingestive behavior } \\
\hline a) Feeding & Bird's head is located inside feeder \\
\hline b) Drinking & Bird's beak is in contact with drinker. \\
\hline \multicolumn{2}{|c|}{ Movement activity } \\
\hline $\begin{array}{l}\text { a) Standing } \\
\text { b) Sitting }\end{array}$ & $\begin{array}{l}\text { Both feet are in contact with the floor; no other body part is in contact with floor. } \\
\text { Most of the ventral region of the bird's body in contact with floor. No space is } \\
\text { visible between the floor and the bird. }\end{array}$ \\
\hline
\end{tabular}

c) Walking Bird is in the process of taking at least 2 steps, including scratching the litter.

\section{Relative weights of internal organs}

At the end of the experiment at 72 day of age, 3 birds from each replicate were randomly selected and weighed then, killed by cutting the neck. After bleeding for few minutes, scalding, defeathering and evisceration was performed manually. The weights of liver, gizzard, proventriculus, heart, spleen were recorded then relative weights were calculated as a percentage of live weight of the birds and the dressed carcass were recorded for each bird.

\section{Blood samples:}

Total 36 blood sample was collected (3 birds/replicate) were collected at the end of experiment. These samples were collected from cutting jugular vein during stunting in $5 \mathrm{ml}$ sterilized syringes and pooled from each replicate, and 12 blood samples were analyzed.

After collecting blood the syringes were kept in slanted position then centrifuged $(3,000 \times \mathrm{g}$ for 10 min) and serum was separated, then stored at $-20{ }^{\circ} \mathrm{C}$ until assayed for measuring biochemical parameters (total protein, albumin, calcium and phosphorus) using appropriate laboratory kits (Gowenlock et al., 1988).

\section{Statistical Analysis}

The results were subjected to statistical analysis using One-way ANOVA for completely randomized design. Treatment means were compared by Duncan test through SPSS (1999).

\section{RESULTS}

Data present in tables (3-5) cleared that, addition of turmeric powder increased significantly body weight, feed intake, body weight gain, total protein, globulin, calcium, phosphorus, FCR, and dressing percentage while, there are non significant effect in albumin level, relative weights of liver, gizzard, heart and spleen over six weeks of experimental period. 
Table 3: Growth performance parameters of broilers fed different experimental diets.

\begin{tabular}{cccc}
\hline & \multicolumn{3}{c}{ Turmeric powder (\%) } \\
\hline Groups & Control & $\mathrm{T}_{1}$ & $\mathrm{~T}_{2}$ \\
weeks & $0 \%$ & $0.5 \%$ & $0.75 \%$ \\
\hline Initial body weight, $g$ & $326.7 \pm 7.3$ & $324.3 \pm 6.5$ & $322 \pm 5.3$ \\
\hline Final body weight, g & $881.6 \pm 6.7^{\mathrm{b}}$ & $1036.7 \pm 2.5^{\mathrm{a}}$ & $1055 \pm 15.3^{\mathrm{a}}$ \\
\hline Body weight gain, $\mathrm{g}$ & $554.9 \pm 4.3^{\mathrm{b}}$ & $712.4 \pm 3.50^{\mathrm{a}}$ & $733 \pm 5.36^{\mathrm{a}}$ \\
\hline Feed intake, g & $1687 \pm 6.3^{\mathrm{b}}$ & $2006.5 \pm 8.3^{\mathrm{a}}$ & $2052.4 \pm 4.3^{\mathrm{a}}$ \\
\hline Feed conversion ratio & $3.04 \pm 0.9^{\mathrm{a}}$ & $2.8 \pm 0.11^{\mathrm{b}}$ & $2.8 \pm 0.18^{\mathrm{b}}$
\end{tabular}

Values are expressed as means \pm standard error (SE).

Means within the same row of different litters are significantly different at $(\mathrm{P}<0.05)$.

Table 4: Carcass traits of broilers fed different experimental diets.

\begin{tabular}{cccc}
\hline & \multicolumn{3}{c}{ Turmeric powder (\%) } \\
\cline { 2 - 4 } Parameters & $\begin{array}{c}\text { Control } \\
\mathbf{0} \%\end{array}$ & $\begin{array}{c}\text { T1 } \\
\mathbf{0 . 5} \%\end{array}$ & $\begin{array}{c}\text { T2 } \\
\mathbf{0 . 7 5} \%\end{array}$ \\
\hline Dressing \% & $69 \pm 0.79^{\mathrm{b}}$ & $73 \pm 0.29^{\mathrm{a}}$ & $74^{\mathrm{a}} \pm .^{\mathrm{a}}$ \\
\hline Proventriculus \% & $0.43 \pm 0.09$ & $0.44 \pm 0.05$ & $0.44 \pm 0.06$ \\
\hline Gizzard \% & $1.41 \pm 0.09$ & $1.43 \pm 0.3$ & $1.44 \pm 0.2$ \\
\hline Liver \% & $2.1 \pm 0.07$ & $2.2 \pm 0.04$ & $2.3 \pm 0.07$ \\
\hline Heart \% & $0.58 \pm 0.043$ & $0.56 \pm 0.008$ & $0.59 \pm 0.004$ \\
\hline Spleen \% & $0.19 \pm 0.07$ & $0.21 \pm 0.03$ & $0.22 \pm 0.03$ \\
\hline
\end{tabular}

Values are expressed as means \pm standard error (SE).

Means within the same row of different litters are significantly different at $(\mathrm{P}<0.05)$

Table 5: Blood biochemical parameters of broilers fed different experimental diets.

\begin{tabular}{cccc}
\hline & \multicolumn{3}{c}{ Turmeric powder (\%) } \\
\cline { 2 - 4 } Parameters & Control & $\mathbf{T 1}$ & T2 \\
& $\mathbf{0 \%}$ & $\mathbf{0 . 5} \%$ & $\mathbf{0 . 7 5} \%$ \\
\hline Total protein $(\mathrm{g} / \mathrm{dl})$ & $3.2 \pm 0.31^{\mathrm{b}}$ & $3.9 \pm 0.07^{\mathrm{a}}$ & $4.4 \pm 0.19^{\mathrm{a}}$ \\
\hline Albumin $(\mathrm{g} / \mathrm{dl})$ & $1.9 \pm 0.02$ & $1.8 \pm 0.0 .3$ & $2.1 \pm 0.03$ \\
\hline Globulin $(\mathrm{g} / \mathrm{dl})$ & $1.3 \pm 0.29^{\mathrm{b}}$ & $2.1 \pm 0.04^{\mathrm{a}}$ & $2.3 \pm 0.22^{\mathrm{a}}$ \\
\hline Calcium $(\mathrm{mg} / \mathrm{dl})$ & $9.8 \pm 0.29^{\mathrm{b}}$ & $11.6 \pm 0.39^{\mathrm{a}}$ & $11.9 \pm 0.43^{\mathrm{a}}$ \\
\hline Phosphorus $(\mathrm{mg} / \mathrm{dl})$ & $7.8 \pm 0.37^{\mathrm{b}}$ & $8.7 \pm 0.12^{\mathrm{a}}$ & $8.9 \pm 0.23^{\mathrm{a}}$ \\
\hline
\end{tabular}

Values are expressed as means \pm standard error (SE).

Means within the same row of different litters are significantly different at $(\mathrm{P}<0.05)$

Figures 1,2,3 and 4 showed that, there a significant increase in feeding, drinking and sitting behavior in treated group compared with control one while, a significant decrease in walking and standing behavior. 


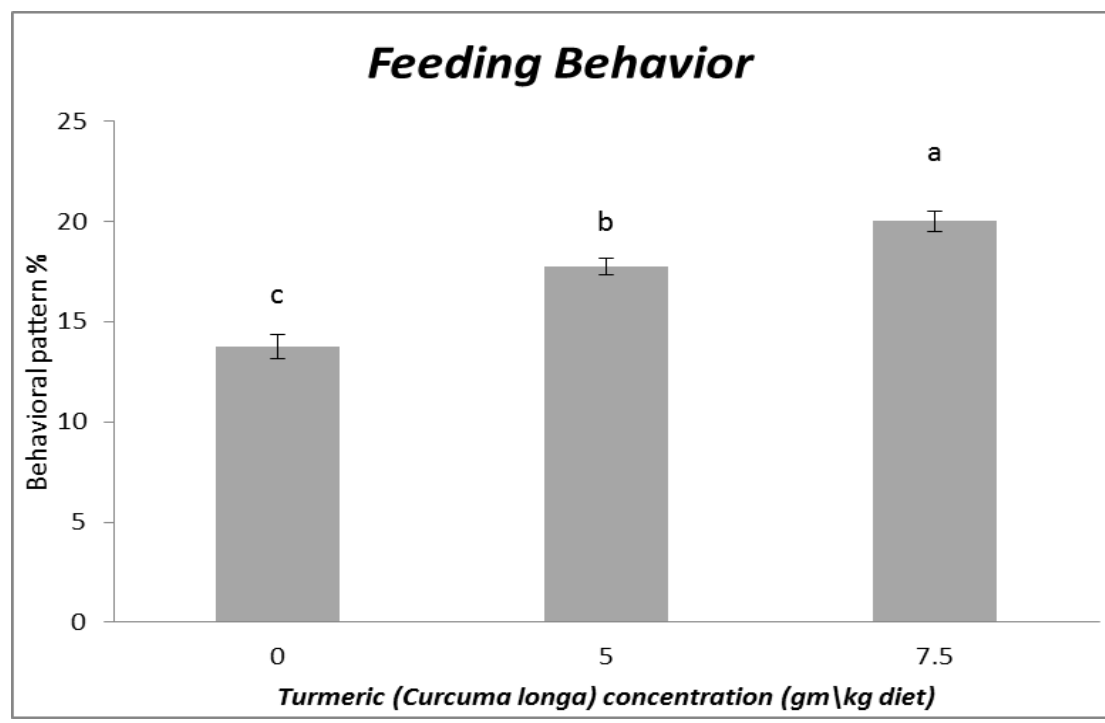

Fig. (1): Shows feeding behavior of broilers fed different experimental diets.

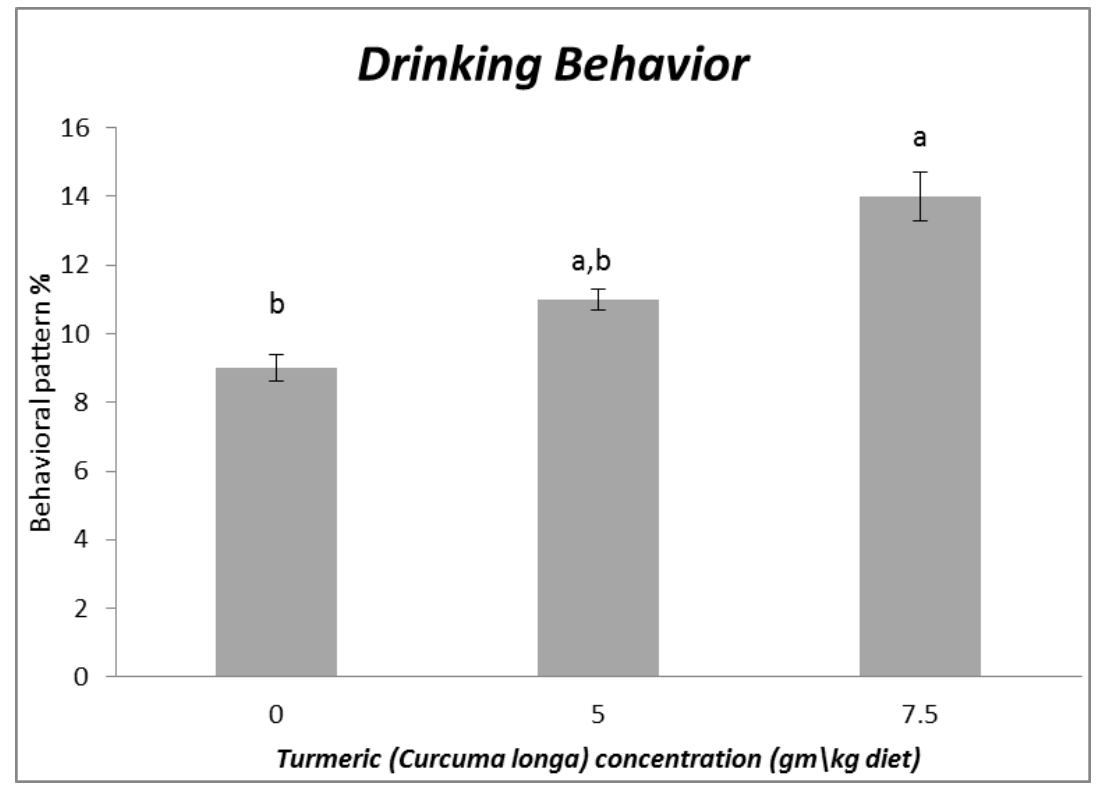

Fig. (2): Shows drinking behavior of broilers fed different experimental diets.



Fig. (3): Shows waking behavior of broilers fed different experimental diets. 


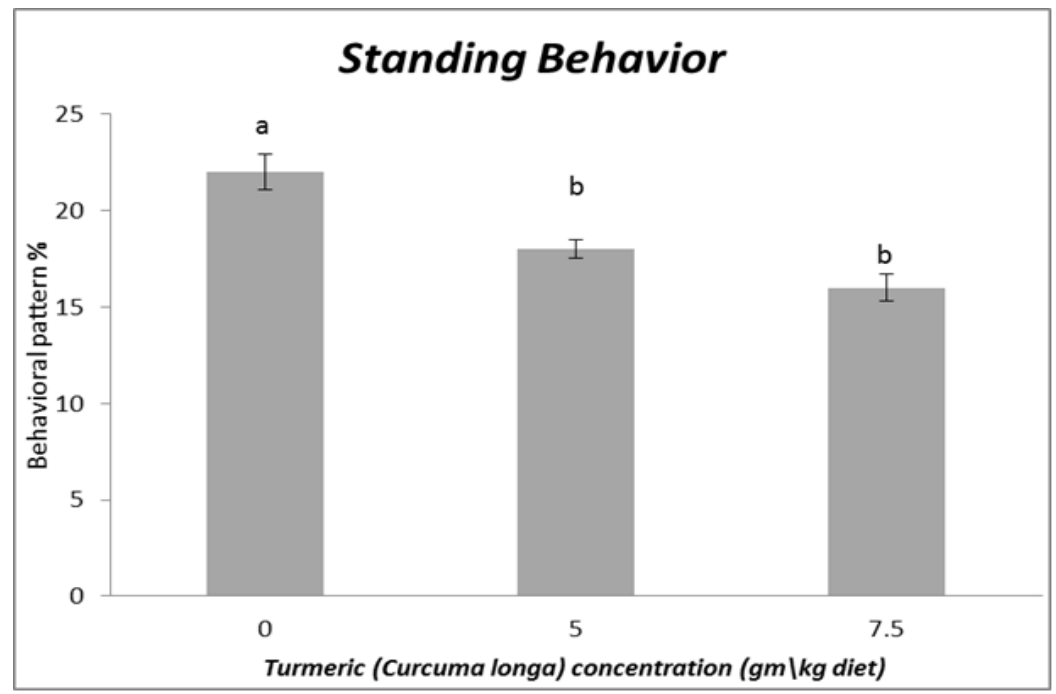

Fig. (4): Shows standing behavior of broilers fed different experimental diets.

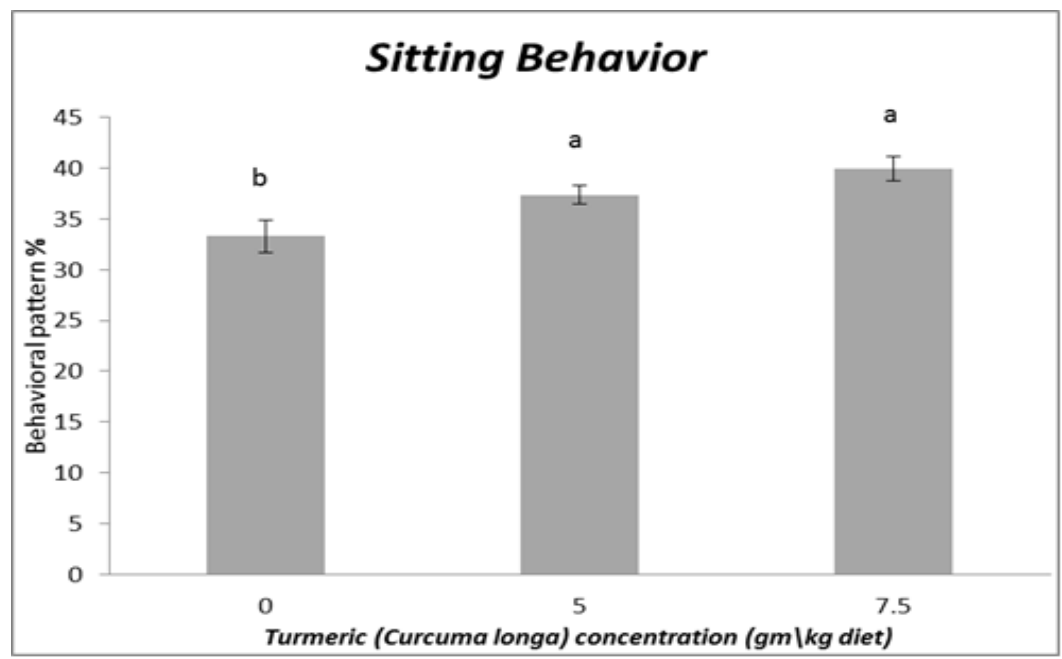

Fig. (5): Shows Sitting behavior of broilers fed different experimental diets a,b,c Means within the same row with different superscripts are significantly different $(\mathrm{P}<0.05)$

\section{DISCUSSION}

The significant increase $(\mathrm{P}<0.05)$ in feed intake and feeding behavior was observed in treated groups and the lowest was recorded in control group which mean that the supplementation of turmeric powder at 0.5 and $0.75 \%$ improved feed intake. Similar findings with respect to improvement of feed intake were observed by several workers (Malekizadeh et al., 2012; Sharma et al., 2015 and Hady et al., 2016). In contrary to the present observations, Nouzarian et al. (2011), Al-Jaleel, (2012) and Rajput et al. (2013) reported no significant difference, also, Hilal and Canan, (2017) and Arslan et al. (2017) reported a reduced in feed consumption. The increased feed intake might be due to addition of turmeric powder possesses appetite stimulant, stomachic and carminative properties (Platel and Srinivasan, 2004 and Chakraborty et al., 2011), also the activity of turmeric as an antioxidant that stimulated protein synthesis (Osawa et al., 1995) by birds' enzymatic system. Moreover, the significant increase in sitting behavior with decrease of walking and standing behavior of a bird accompanied with an increase in feed intake that, might be leading to heavy body weight of bird which reduce the chicken's activity (Weeks et al., 2000).

Body weight and body weight gain differed significantly $(\mathrm{P}<0.05)$ among the different treated groups. Groups (1\&2) achieved significantly higher body weight as compared to control one. Similar observations were reported by Mashhadani, (2015) and Sethy et al. (2016). Contrary to the present finding, Mehala and Moorthy, (2008) and Nouzarian et al. (2011) reported that body weight was not affected by dietary supplementation of turmeric powder in broiler chicken. On other hand, the improvement of body gain was reported by previous work of Mondal et al. (2015), Sharma et al. (2015), 
Sethy et al. (2016) and Arslan et al. (2017). Moreover, improvement of FCR was agreed with the finding of several workers of Hilal and Canan, (2017) and Arslan et al. (2017).

While, our result disagreed with (Mehala and Moorthy, 2008, Vashan et al., 2012 and Fallah and Mirzaei, 2016) who reported non significant finding in FCR due to using of turmeric powder. The wide range of performance results may be attributed to the dose, form, duration of processing of medicinal plants and experimental condition.

The improvement in body weight and body weight gain of the broiler chickens may due to several causes as appetizer effects of turmeric increasing gastric digestion liquor (William and Losa 2001), increased villus length and width in the duodenum, jejunum and caeca of broiler chickens (Rajput et al., 2013); enhanced production of the bile, which improves the digestion of fats (Al-Sultan and Gameel, 2004); increase pancreatic lipase activity, increased amylase, trypsin and chemotrypsin (Chattopadhyay et al., 2004); stimulate the intestinal sucrose and maltase activities (Platel and Srinivasan, 1996); forming more balanced intestinal flora due to their antimicrobial effects (Erhan et al., 2012); decreased the intestinal microbes' population and selectively increased Lactobacillus count (Sieo et al., 2005 and Namagirilakshmi et al., 2010). The reduction in microbial load of broiler chickens could be due to the antibacterial effect of turmeric on intestinal microbial (Faghani et al., 2014) which reflected mainly to more feed intake and more digestion.

\section{Relative weights and biochemical parameters}

The inclusion of turmeric powder into fayoumi broilers increased significantly dressing percentages, while did not affect significantly on relative weights of liver, gizzard, heart and spleen. These results agreed with Durrani et al. (2006) and Al-Jaleel (2012) while disagreed with the finding of Mashhadani (2015); Kafi et al. (2017) and Hilal and Canan, (2017).

The significant increase in total protein, globulin, calcium and phosphorus level with no effect on albumin level, agreed with the results reported by Rao et al. (1970) who found that, serum total protein of broilers fed turmeric powders can improve protein metabolism of broiler chickens. This effect can be probably explained by these medicinal plants can promote protein deposition in broilers "in vivo" maintain a stable colloid osmotic pressure, improve the transportation of metabolic products, improve feed conversion rate and promote growth. Moreover, Zhu et al. (2014) found an increase in seric globulins; protective effects on cells via enzymatic and nonenzymatic mechanisms, while, disagreed with Abou-
Elkhair et al. (2014) who found no significant effect on total protein and albumin.

\section{CONCLUSION}

Using turmeric (curcuma longa) powder supplement in fayoumi broiler diets improved body weigh gain, FCR, and Ingestive behavior. In addition, total protein, globulin, calcium, phosphorus and dressing percentage were increased significantly.

\section{ACKNOWLEDGEMENT}

I'm grateful to members of Animal and poultry behavior and management department, Faculty of Veterinary Medicine, Assiut University, Egypt for their guidance in experimental done, writing and publishing of this article.

\section{REFERENCES}

Abou-Elkhair, R.; Ahmed H.A. and Selim, S. (2014): Effects of black pepper (Piper Nigrum), turmeric powder (Curcuma Longa) and Coriander Seeds (Coriandrum Sativum) and their combinations as feed additives on growth performance, carcass traits, some blood parameters and humoral immune response of broiler chickens. Asian Australas. J. Anim. Sci. 27(6): 847-854.

Al-Jaleel, RAA. (2012): Use of turmeric (Cucuma longa) on the performance and some physiological traits on the broiler diet. The Iraqi Journal of Veterinary Medicine, 36(1): 51-57.

Al-Sultan, S.I. and Gameel, A.A. (2004): Histopathological changes in the liver of broiler chickens supplemented with turmeric (Curcuma longa). Int. J. Poult. Sci. 3: 333-336.

Altmann, J. (1974): Observational study of behavior. Sampl. Methods Behav.49, 227-266.

Arslan, M.; UlHaq, A.; Ashraf, M.; Iqbal, J. and Mund, MD. (2017): Effect of turmeric (Curcuma longa) supplementation on growth performance, Immune response, Carcass characteristics and Cholesterol Profile in broilers. Veterinaria, 66(1): 16-20.

Chakraborty, PS.; Ali, SA.; Kaushik, S.; Ray, RK.; Yadav, RP.; Rai, MK.; Singh, D.; Bhakat, AK.; Singh, VK.; John, MD.; Das, KC.; Prasad, VG. and Nain, SS. (2011): Curcuma longa- A multicentric clinical verification study. Indian Journal of Research in Homeopathy, 5(1): 19-27.

Chattopadhyay, I.; Biswas, K.; Bandyopadhyay, $U$. and Banerjee, R.K. (2004): Turmeric and curcumin: Biological actions and medicinal applications. Current Science. 87(1):44-53.

Durrani, FR.; Ismail, M.; Sultan, A.; Suhail, SM.; Chand, N. and Durrani, Z. (2006): Effect of 
different levels of feed added turmeric (Curcuma longa) on the performance of broiler chicks. Journal of Agricultural and Biological Science 1: 9-11.

Erhan, M.K.; Bölükbaşi, Ş.C and Ürüşan H. (2012): Biological activities of pennyroyal (Menthapulegium L.) in broilers. Livestock Sci. 146: 189-192.

Faghani, M.; Rafiee, A.; Namjoo, A.R. and Rahimian, $Y$. (2014): Performance, cholesterol profile and intestinal microbial population in broilers fed turmeric extract. Research Opinion of Animal and Veterinary Science, 4(9): 500-503.

Fallah, R. and Mirzaei, E. (2016): Effect of dietary inclusion of turmeric and thyme powders on performance, blood parameters and immune system of broiler chickens. Journal of Livestock Science, 7: 180-186.

Gowenlock, AH.; Mcmurray, JR. Mclauchlan, DM. (1988): Varley,s practical clinical biochemistry. $6^{\text {th }}$ Ed.CAS. Publishers and Distributors, New Delhi. 477- 549.

Hady, MM.; Zaki, MM.; Wafaa Abd EL-Ghany, WA.; Reda and Korany, MS. (2016): Assessment of the broilers performance, gut healthiness and carcass characteristics in response to dietary inclusion of dried coriander, turmeric and thyme.International Journal of Environmental and Agricultural Research,, 2(6): 153-159.

Hilal Ürüşan, and Canan Bölükbaşı (2017): Effects Of Dietary Supplementation Levels Of Turmeric Powder (Curcuma Longa) On Performance, Carcass Characteristics And Gut Microflora In Broiler Chickens. The Journal of Animal \& Plant Sciences, 27(3): 2017, Page: 732-736

Kafi, A.; Uddin, M.N.; Uddin, M.J.; Khan, M.M.H. and Haque, M.E. (2017): Effect of dietary supplementation of turmeric (Curcuma longa), ginger (Zingiberofficinale) and their combination as feed additives on feed intake, growth performance and economics of broiler. Int. J. Poult. Sci., 16: 257-265.

Kristensen, H.H.; Aerts, J.M.; Leroy, T.; Wathes, C.M. and Berckmans, D. (2006): Modelling the dynamic activity of broiler chickens in response to step-wise changes in light intensity. Appl. Anim. Behav. Sci. 101, 125-143.

Malekizadeh, M.; Moeini, M.M. and Ghazi, Sh. (2012): The Effects of Different Levels of Ginger (ZingiberofficinaleRosc) and Turmeric (Curcuma longa Linn) Rhizomes Powder on Some Blood Metabolites and Production Performance Characteristics of Laying Hens. J. Agr. Sci. Tech. (2012) Vol. 14: 127-134

Mashhadani, HE. (2015): Effect of different levels of turmeric (Curcuma longa) supplementation on broiler performance, carcass characteristic and bacterial count. Egyptian Poultry Science Journal, 35(1): 25-39.
Mehala, C. and Moorthy, M. (2008): Production Performance of Broilers Fed with Aloe veraand Curcuma longa (Turmeric). International Journal of Poultry Science, 7 (9): 852-856.

Mondal, MA.; Yeasmin, T.; Karim, R.; Siddiqui, MN.; Raihanun-Nabi, SM.; Sayed, MA. and Siddiky, MNA. (2015): Effect of dietary supplementation of turmeric (Curcuma longa) powder on the growth performance and carcass traits of broiler chicks. SAARC Journal of Agriculture, 13(1): 188-199.

Namagirilakshmi, S.; Selvaraj, P.; Nanjappan, K.; Jayachandran, S. and Visha, P. (2010): Turmeric (Curcuma longa) as an alternative to in-feed antibiotic on the gut health of broiler chickens.Tamilnadu Journal of Veterinary and Animal Science, 6 (3): 148-150.

Nazeer, M.S.; Pasha, T.N.; Abbas, S. and Ali, Z. (2002): Effect of Yucca Saponin on unease activity and developmeny of ascities in broiler chickens. Int. J. Poult. Sci., 1: 174-178.

Nouzarian, R.; Tabeidian, SA.; Toghyani, M.; Ghalamkari, G. and Toghyani, M. (2011): Effect of turmeric powder on performance, carcass traits, humoral immune responses, and serum metabolites in broiler chickens.Journal of Animal and Feed Science, 20: 389-400.

Osawa, T.; Sugiyama, Y.; Inayoshi, M. and Kawakishi, S. (1995): Antioxidant activity of tetrahydrocurcuminoids. Bioscience Biotechnology and Biochemistry, 59: 16091612.

Platel, K. and Srinivasan, K. (1996): Influence of dietary spices or their active principles on digestive enzymes of small intestinal mucosa in rats. Int. J. Food Sci Nutr. 47(1): 55- 59.

Platel, K. and Srinivasan, K. (2004): Digestive stimulant action of spices: a myth or reality? Indian Journal of Medical Research, 119(5): 167-179.

Prasad S.; Tyagi, AK. and Aggarwal, BB. (2014): Recent developments in delivery, bioavailability, absorption and metabolism of curcumin: the golden pigment from golden spice. Cancer Res Treat.; 46(1):2-18.

Qasem, MAA.; Alhajj, MS.; El Nabi, ARG. and AlMufarrej, SI. (2015): Effect of turmeric powder as a dietary supplement on performance indicators and immune responses in broiler chickens. Journal of Animal and Veterinary Advances, 14(2): 30-35.

Rahman, S.; Mostofa, M.; Fatema, MN.; Latif, MA. and Afrin, S. (2014): Effect of neem leaves, turmeric and cinnamon extract as a growth promoter in broilers. Bangladesh Research Publications Journal, 10(1): 7-13.

Rajput, N.; Muhammad, N.; Yan, R.; Zhong, X. and Wang, T. (2013): Effect of dietary supplementation of Curcumin on growth performance, intestinal morphology and 
nutrients utilization of broiler chicks.Journal of Poultry Science, 50(1): 44-52.

Ramadan, H.A.I.; Galal, A.; Fathi, M.M.; El Fiky, S.A. and Yakoub, H.A. (2011): Characterization Of Two Egyptian Native Chicken Breeds Using Genetic And Immunological Parameters. Biotechnology in Animal Husbandry 27 (1), p 1-16

Rao, SD.; Chandrashekhara, N.; Satyanarayana, MN. and Srinivasan, M. (1970): Effect of curcumin on serum and liver cholesterol levels in the rat. Journal of Nutrition 100: 1307-1315.

Sethy, K.; Swain, P.; Behera, K.; Nayak, SM.; Barik, SR.; Patro, P. and Meher, P. (2016): Effect of turmeric (Curcuma longa) supplementation on growth and blood chemistry of broilers. Exploratory Animal and Medical Research, 6(1): 75-79.

Sharma, A.; Ranjan, S. and Krishna, V. (2015): Evaluation of Growth Promoter-Boon and Its Effect on Growth Performance of Broilers. International Journal of Advanced Biotechnology and Research, 6(3): 366-371.

Sieo, CC.; Abdullah, N.; Tan, WS. and Ho, YW. (2005): Influence of beta-glucanase producing Lactobacillus strains on intestinal characteristics and feed passage rate of broiler chickens. Poultry Science 84: 734-741.

SPSS (1999): SPSS for Windows Release 10.1, SPSS Inc.

Valenzuela-Grijalva, NV.; Pinelli-Saavedra, A.; Muhlia-Almazan, A.; Domínguez-Díaz, D. and
González-Ríos, H. (2017): Dietary inclusion effects of phytochemicals as growth promoters in animal production. J Anim. Sci Technol; 59:8.

Vashan, SJH.; Golian, A.; Yaghobfar, A.; Zarban, A.; Afzali, N. and Esmaeilinasab, P. (2012): Antioxidant status, immune system, blood metabolites and carcass characteristic of broiler chickens fed turmeric rhizome powder under heat stress. African Journal of Biotechnology, 11(94): 16118-16125.

Weeks, C.A.; Danbury, T.D.; Davies, H.C.; Hunt, P. and Kestin, S.C. (2000): The behaviour of broiler chickens and its modification by lameness. Applied animal behaviour science, 67(1-2), 111-125.

William, P. and Losa, R. (2001): The use of essential oils and their compounds in poultry nutrition. World Poult. 17:14-15.

Zhang, G.F.; Yang, Z.B.; Wang, Y.; Yang, W.R.; Jiang, S.Z. and Gai, G.S. (2009): Effects of ginger root (Zingiberofficinale) processed to different particle sizes on growth performance, antioxidant status and serum metabolites of broiler chickens. Poult. Sci., 88: 2159-2166.

Zhu, X.; Liu, W.; Yuan, S. and Chen, H. (2014): The effect of different dietary levels of thyme essential oil on serum biochemical indices in Mahua broiler chickens. Ital. J. Anim. Sci. 13, 576-581.

\section{تاثير تغذيه مسحوق الكركم على الاداء الانتاجى والسلوك والقياسات البيوكيميائيه فى الاجاج الفيومى}

\section{مليحه حنى درويش ، رمضان دردير الثقيرى}

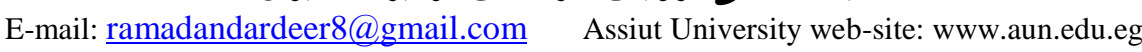

اجريت هذه الدر اسة لتقييم تغذية مسحوق الكركم على كفاءة الاداء وخصائص الذبائح و السلوك في بدارى الاجاج الفيومى المحلى. تم

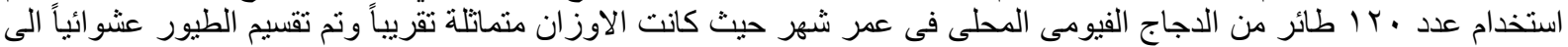

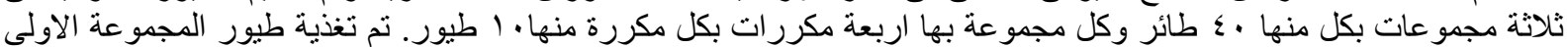

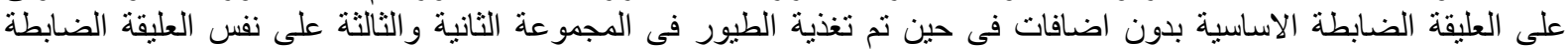

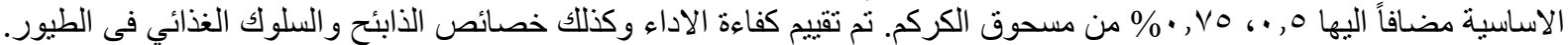

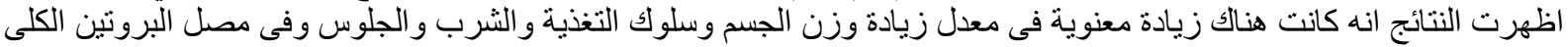

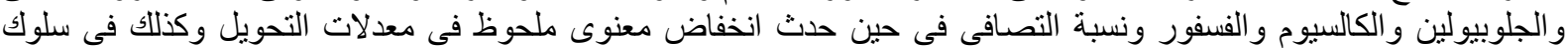

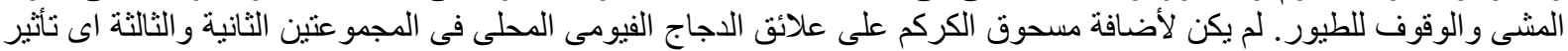

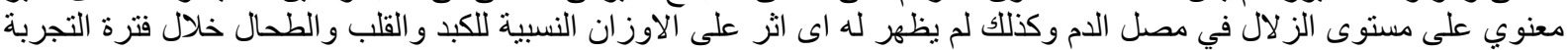

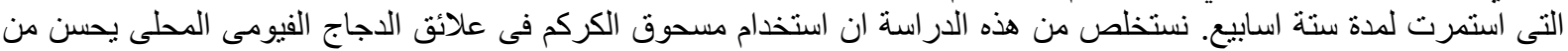

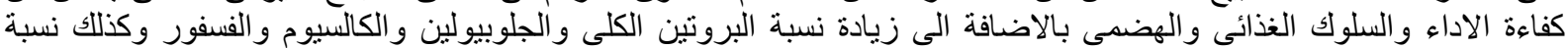
التصافي للذبائح بشكل معنوى ملحوظ. 